\title{
Narratives from within: an Arendtian approach to life histories and the writing of history
}

Maria Tamboukou, cCentre for Narrative Research, University of East London, UK.

\begin{abstract}
In this paper I draw on my current research of writing a genealogy of women artists, focusing in particular on the life history of the American working class artist, May Stevens (1924-). I am particularly interested into how an analysis of the textual and visual narratives in her work, seen in the context of her life history can intervene in the formation of historical discourses around gender and art education, a grey area that I suggest needs to be further explored. In looking into the interrelation between life histories and the writing of history, I follow Hannah Arendt's conceptualization of biographies within the political and I highlight the importance of history painting in creating critical communities of remembrance. I argue that this is where gender becomes crucially important: not just as an analytic category as influentially theorized by Joan Scott but as a politically situated position for re-imagining women as historical subjects and thus rewriting history.
\end{abstract}

Keywords: Arendt, art education, life histories, visual narratives, women artists

In her 1985 influential essay, 'Gender: A Useful Category of Historical Analysis', Joan Scott defined gender on two interrelated levels, the social and the political: 'gender is a constitutive element of social relationships based on perceived differences between the sexes and gender is a primary way of signifying relationships of power.' In charting the plane of the social, she proposed four fields for future research and analysis: a) interrogating dominant representations of gender, b) challenging normative concepts that underpin constructions of meanings and interpretations, c) situating the analysis within specific socio-political contexts and d) developing socio-historical analyses of the constitution of subjective identity. ${ }^{2}$ Turning to the political plane of analysis Scott further raised a series of critical questions that would position gender at the heart of political history. 'Why (and since when)' she asked amongst others 'have women been invisible as historical subjects when we know they participated in the great and small events of human history?'

Scott's contention was that although feminist historians had already developed multiple and interdisciplinary levels of analysis there was still a need for going beyond descriptive analyses, for making theoretical syntheses and analytical connections and for working more against the marginalization of gender based analyses in the field of history, so that dominant concepts and perceptions could be transformed. ${ }^{4}$

Over the last 25 years since Scott's essay feminist theorists have certainly created a rich field of scholarship wherein gender has shaped research questions, analytical concepts and methodological strategies. In this context, women's marginal position in administration and policy making in education has been a hot area wherein gender oriented analyses have created conditions of possibility for the emergence of historically significant changes. However the two planes that Scott pointed to back in 1985 still require attention, sometimes in frightfully urgent ways, particularly vis-à-vis the ever-present problem of marginalization of feminist studies not only in the field of history but in the academy more widely. What I will therefore argue in this paper is that bringing together art, gender and education is such a field in need of further work and research and writing feminist genealogies of women artists has been my way of contributing to it.

\footnotetext{
${ }^{1}$ Joan, W. Scott, 'Gender: A Useful Category of Historical Analysis' in Feminism and History, ed, J. Scott (Oxford: Oxford University Press, 1997), 167. This essay was first presented at the meetings of the American Historical Association in December 1985 and was subsequently published in The American Historical Review, 91/5 (December, 1986).

${ }^{2}$ Ibid., 167-169.

${ }^{3}$ Ibid., $174-5$.

${ }^{4}$ Ibid., 154.
} 
In explicating the fourth level of social analytics of gender, namely the constitution of subjective identity, Scott had identified biographies as 'the best efforts in this area so far. ${ }^{, 5}$ Indeed, feminist analyses of women's auto/biographical narratives have become a rich interdisciplinary field in the theorization of women's subjectivity since Scott's essay, while her similarly influential essay on the evidence of experience ${ }^{6}$ has greatly shaped the analytics of this field?

In thus mapping my on-going work of writing feminist genealogies in Scott's cartography for research informed by gender as an analytical category, in this paper I am looking into textual and visual narratives revolving around May Stevens (1924-), an American working-class feminist artist. I have been particularly interested in how Stevens' positioning in terms of gender and social class have had salient effects on specific life choices, particularly in terms of spatial mobility, professional orientations and political activism. Focusing in particular on Stevens' history paintings I have further been interested in the influence of the class/gender intersection upon the subject matter, but also the aesthetics and politics of her artwork, that as I will further argue create an exemplary case for an Arendtian approach to life histories and the writing of history. ${ }^{9}$

\section{Life is a Narrative}

As Julia Kristeva has noted, Hannah Arendt was 'a fervent admirer of the "narrated life", of bios-graphie. ${ }^{10} \mathrm{~A}$ central understanding in Arendt is that life histories create meaning by recalling events and recounting actions and thus "remembering and communicating ... is at the core of story telling." In this light, story making for Arendt fulfills life as it contributes to the pursuit of both meaning and action: 'the revelatory character of action as well as the ability to produce stories and become historical, which together form the very source from which meaningfulness springs into and illuminates human existence. ${ }^{12}$

Arendt's understanding of the biographical discourse is quite unique however. Life histories generate meaning, but this meaning is only accessible to the tellers and listeners of the stories, not to their protagonists. This is because human beings live fragmented lives whose meaning always evade them; they thus need others to tell their stories and create archives for historical understanding. It is this idea of a life lived as action that can be narrativized and shared by others who did not necessarily participate in the narrated action that makes the Arendtian conceptualization of narratives so compelling and so relevant to her overall work as a political philosopher.

Indeed, Arendt's philosophical take on biography suggests that 'we need to find a discourse, a lexis, that can answer the question "Who are you?" [...] Narrative will fulfill this role, the invented story that accompanies history. ${ }^{13}$ What is exactly the relationship between the 'invented story' and history? In Arendt's thought, Kristeva notes, there is a discrepancy between the actor and what constitutes a heroic action. Actors make history only if their action is recorded and becomes memorable and this memoralization is the role of narratives: 'One immortalizes one's self by becoming a "who" that acts within political space, thus giving rise only to a memorable narrative. ${ }^{11}$ How is this memory constituted? 'It is spectators who complete the story in question, and they do so through thought, thought that follows upon the act. This is a completion that takes place through evoked memory, without which there is nothing to tell. ${ }^{, 5}$ In this light, life story and history are

${ }^{5}$ Ibid, 169.

${ }^{6}$ Joan, W. Scott, 'The Evidence of Experience', Critical Inquiry 17 (Summer 1991), 773-797.

${ }^{7}$ See Maria Tamboukou, Women, education and the Self (Basingstoke: Palgrave, Macmillan, 2003), particularly Chapter

One, for an overview of the field of women's autobiographical narratives and a discussion of Scott's contribution in it.

${ }^{8}$ Tamboukou, Women, education and the Self.

${ }^{9}$ For an overview of Stevens' paintings, see http://www.artcyclopedia.com/artists/stevens may.html

${ }^{10}$ Julia Kristeva, Life is a Narrative (Toronto: University of Toronto Press, 2001), 6.

${ }^{11}$ Liliane Weissberg, 'Introduction: Hannah Arendt, Rahel Varnhagen and the Writing of (Auto)biography', in H. Arendt Rahel Varnhagen: The Life of a Jewess, ed. L. Weissberg (Baltimore: The Johns Hopkins University Press, 2000), 21.

${ }^{12}$ Arendt, cited in Kristeva, Life is a Narrative, 9.

${ }^{13}$ Ibid., 15.

${ }^{14}$ Ibid., 19.

${ }^{15}$ Ibid., 16. 
bound together in Arendt's philosophy and the role of the biographer becomes important not just for the writing of the story but for the (re)writing of history itself.

In this light, what has particularly intrigued me with May Stevens is that through her art she has assumed the role of the artist/biographer by drawing on women's stories, incorporating them in the subject matter of her art and attempting to rewrite the canon of history painting and thus re-imagine women's history within it.

\section{Art in Stories, Stories in Art}

I love story, I love narrative. I use it in my work. I tell stories. The stories are anecdotes about events. And they're selected because they mean something to me. I choose them because I see meaning in them. ${ }^{16}$

On May 23, 1997, the Alumni Association of the Massachusetts College of Art honoured May Stevens as a Distinguished Alumna of the College, noting that 'widely acclaimed for her achievements in the visual arts, she has secured a place in history.' ${ }^{17}$ The only girl in a family of three children, Stevens was born in Quincy Massachusetts in 1924; her father was a pipefitter and her mother a housewife. Coming from a working-class family background, it is not surprising then that Stevens was the first member of her family to go to college. As Mara Witzling has noted, afraid that she might ended up as a schoolteacher, Stevens specifically chose the Massachussettes College of Art (MassArt) in Boston as an established art institution that would safeguard her career as an artist. ${ }^{18}$ Stevens has vividly recounted her memories from MassArt and particularly the 'promise' to her favourite art teacher to overcome gender and class barriers and follow the dream of becoming an artist:

My favourite teacher, my painting teacher, was Otis Philbrick, the acting president of the school. He liked my painting a lot, and he said he wanted me to promise him that I would never give up painting. I thought that was wonderful. It indicated that he understood how hard was for a woman to go on because they usually got married and had children. They don't become painters. But I promised him. ${ }^{19}$

As an aspiring woman artist from a working class family, Stevens was clearly right to be worried. Although art education became available for working class people in general and working class women in particular in the late part of the nineteenth century, the kind of art education that 'the masses' could have access to, was far away from the idea of Classical Art. As Pen Dalton's study has shown, in the context of the nineteenth century art education was deployed as a gendered discourse and was deeply shaped by the needs of industrial modernization..$^{20}$ Art education was therefore both classed and gendered and this historical legacy has lived up to our own days.

What is particularly notable in Stevens' story however, is her choice of MassArt as a safe art college that would protect her from becoming a schoolteacher. It is indeed interesting to look back into the history of this art college, which was founded in 1873 as the Massachusetts Normal Art School (MNAS). ${ }^{21}$ As an art educational institution MNAS was a response to the growing demand for art teachers after the 1870 Industrial Drawing Art that made art education compulsory for all children in public schools in the United States. MNAS would waive fees for students on the condition that upon their graduation, they would reside in Massachusetts and teach in public schools. It goes without saying that women comprised the majority of the body of teachers to be trained in art education and consequently of the student population of MNAS. ${ }^{22}$ In

\footnotetext{
${ }^{16}$ May Stevens in conversation with Patricia Hills. Patricia Hills, May Stevens (San Francisco: Pomegranate, 2005$), 11$.

${ }^{17}$ Hills, May Stevens, 17.

${ }^{18}$ Mara R. Witzling, 'May Stevens', in Voicing Today's Visions: Writings by Contemporary Women Artists, ed. M.R. Witzling (New York: Universe Publishing, 1997), 66.

${ }^{19}$ Hills, May Stevens, 17.

${ }^{20}$ Pen Dalton, The Gendering of Art Education (Buckingham: Open University Press, 2001).

${ }^{21}$ I have written extensively elsewhere about the history of MNAS and I worked in its archives in March-April 2006. (See, Maria Tamboukou, 'Machinic Assemblages: Women, Art Education and Space', Discourse: Studies in the Cultural Politics of Education, 29, no. 3 (2008): 359-375.

${ }^{22}$ Massachusetts College of Arts, Archives, Visionary Education: 125 Years of Massachussetts College of Arts (Boston:
} 
this context, MNAS has been presented and indeed celebrated as a progressive educational institution that made art education accessible to the masses in general and women in particular: 'Massachusetts Normal Art School, revolutionized who could study art [...] At this fledging school, art was reinterpreted as the legitimate domain of working people. ${ }^{, 23}$

As already noted, however, hand in hand with this 'revolution', went a specific vision of what art in general and art education in particular should be about when offered or made accessible to 'the masses'. Walter Smith, the first principal of MNAS who moved from London to Boston to take up this position, was seriously involved in the aesthetics and politics of the Arts and Crafts movement: his vision was to popularize and enshrine art, a project that he was attempting to transfer from South Kensington to Boston. Art historians have indeed placed his project of promoting industrial drawing in the context of the British South Kensington System of Art Education. ${ }^{24}$ As Dalton has pointed out: 'British art education was exported to its colonies in the late nineteenth century through systems such as the South Kensington model [...] and became part of the structuring forms of art education from the United States, Canada and Australasia. ${ }^{25}$

MNAS was therefore initially founded as a college to train art teachers for the needs of the industrialists. However, between 1873 and 1942, which is the year when May Stevens actually enrolled in MassArt, the latter had not simply changed its name; it had been transposed into an institution that would supposedly protect a working-class woman artist from actually becoming a teacher. I have written elsewhere about the processes and effects of such transpositions. ${ }^{26}$ What I want to focus on in this paper however, is the complex interrelation between art, feminism and education in creating a historical consciousness of women's condition and in forming critical communities of remembrance that will fight against what Hannah Arendt has identified as 'the danger of oblivion':

The tragedy began ... when it turned out that there was no mind to inherit and to question, to think about and to remember. The point of the matter is that the 'completion', which indeed every enacted event must have in the minds of those who then are to tell the story and to convey its meaning, eluded them; and without this thinking completion after the act, without the articulation accomplished by remembrance, there simply was no story left that could be told. ${ }^{27}$

As already discussed above, this is where the role of the biographer becomes terribly important for Arendt, as she undertakes the responsibility to uncover the meaning of stories, reveal the who, the unrepeatable uniqueness of human existence and in this way, sustain the mnemonic practices of the social world. In Stevens' life and work however, the figure of the biographer opens up to include the artist, since narratives are not restricted to texts. As Jens Brockmeier has aptly put it:

Pictures and words, imagery and narrativity are interwoven in one and the same semiotic fabric of meaning. They are overlapping trajectories within the same symbolic space, a space of meaning in which our experience takes place and in which we try to make sense of the world. ${ }^{28}$

In making this argument, Brockmeier notes of course that 'narrative should not be understood as a language entity, but in a more general sense as the ability or capacity "to tell a story" [...] A narrative text in this view is a text in which one or more agents tell a story in a particular medium. ${ }^{, 29}$ In this light, all narratives are

Massachussets College of Arts, 1998), 3.

${ }^{23}$ Diana Korzenik, 'The art education of working women, 1873-1903', in From pilgrims and pioneers: New England women in the arts, eds, A. Faxon \& S. Moore (New York: Midmarch Arts Press, 1987), 33.

${ }^{24}$ Mary Ann Stankiewicz, 'From the aesthetic movement to the arts and crafts movement', Studies in Art Education, 33 , no.3 (1992): 165-173.

${ }^{25}$ Dalton, The Gendering of Art Education, 4.

${ }^{26}$ Tamboukou, Machinic Assemblages.

${ }^{27}$ Arendt, cited in Kristeva, Life is a Narrative, 17.

${ }^{28}$ Jens Brockmeier, 'From the end to the beginning', in Narrative and Identity Studies in Autobiography, Self and Culture, eds, J. Brockmeier and D. Carbaugh (Toronto: University of Toronto \& Freie Universität Berlin, University of Massachusetts at Amherst), 255.

${ }^{29}$ Ibid. 
relational acts within Bakhtin's conceptualization of the dialogic nature of human language. ${ }^{30}$ Moreover, the medium in Brockmeier's analysis 'can be language as well as imagery, sound, spatial construction or a combination thereof.' Thus, life histories can be both visual and textual and Stevens' work has forcefully and imaginatively brought them together as I will further show by focusing on a long art project in her work, the Ordinary/Extraordinary series.

\section{Ordinary/Extraordinary}

Ordinary. Extraordinary. A collage of words and images of Rosa Luxemburg, Polish/German revolutionary leader and theoretician, murder victim (1871-1919), juxtaposed with images and words of Alice Stevens (born 1895) housewife, mother, washer and ironer, inmate of hospitals and nursing homes. A filmic sequence of darks and lights moving through close-up to long-view and back. Oblique. Direct. Fragments of Rosa's thought from intimate notes sent from prison to her comrade and lover, Leo Jogiches, and to her friends; from agit-prop published in Die Rote Fächne; and from her serious scientific writings. Images from her girlhood, her middle life, and the final photograph of her murdered head. Alice's words from the memory of and letters to her daughter. An artist's book examining and documenting the mark of a political woman whose life would otherwise be unmarked. Ordinary. Extraordinary. ${ }^{32}$

I was quite moved when I first read this powerful blurb from May Stevens' Artist's Book, which appeared in 1980 in the process of the artist's long preoccupation with Rosa Luxemburg that lasted for over ten years (1977-1991) and again returned as a theme in her work in 2001. ${ }^{33}$ Ordinary/Extraordinary is a poetic way of bringing two very different women together: the artist's mother and a celebrated political theorist and activist. However as Stevens has remarked in her conversation with Patricia Hills, Ordinary/Extraordinary should not be taken as a dualistic opposition between the two women, configuring her mother Alice Stevens as 'ordinary' and Rosa Luxemburg as 'extraordinary':

It was important to me that people realize that both words, 'ordinary' and 'extraordinary', referred to both women. I wanted to make Alice Stevens understood as a woman of a certain character, who was quite unique and impressive in her own way. Rosa Luxemburg, the brilliant theoretician was also a very ordinary human being. I worked with those ideas. ${ }^{34}$

Both women were for Stevens simultaneously ordinary and extraordinary, a thought whose philosophical line can be traced back to Hannah Arendt's argument about the uniqueness of the human condition, the importance of 'who' one is, as juxtaposed to the inevitable and politically dangerous reduction of 'what' one is, that has historically fuelled totalitarian classifications and in turn resulted in gross human rights violations. ${ }^{35}$ In this light, narratives are particularly instrumental in revealing the 'who' and what The Artist's Book in the Ordinary/Extraordinary series creates, is a rich matrix of visual and textual narratives revealing the unrepeatable uniqueness of human beings:

The text in the book consisted of extracts from Rosa Luxembourg's letters and a few lines from her political writings, and the text for Alice was also lines from letters she wrote and postcards she wrote to me, plus a tissue of narrative that was necessary because I didn't have rich written material from my mother. ${ }^{36}$

Epistolary narratives and the force of human communication through writing thus become important compositional elements of the Ordinary/Extraordinary series. As I will further discuss, letters as 'portraits of

\footnotetext{
${ }^{30}$ Michail Bakhtin, The dialogic imagination: Four essays, ed. M. Holquist (Austin: The University of Texas Press, 1981).

${ }^{31}$ Brockmeier, 'From the end to the beginning', 255.

${ }^{32}$ From Ordinary/Extraordinary, The Artist's Book, 1980, cited in M. Witzling, 'May Stevens', 79.

${ }^{33}$ For some images of the Ordinary/Extraordinary series, see, http://www.mfa.org/collections/search_art.asp?coll_keywords=May+Stevens\&coll_has_images=1 and Hills, May Stevens

${ }^{34}$ Hills, May Stevens, 43.

${ }^{35}$ Hannah Arendt, Origins of Totalitarianism, (New York: A Harvest Book, 1985).

${ }^{36}$ Hills, May Stevens, 43.
} 
moments' have been particularly discussed and analyzed in Arendt's work and more specifically in the only biography she ever wrote: Rachel Varnhagen: The Life of a Jewess. ${ }^{37}$ What can be so critical about letters in the genre of life-writing in both textual and visual versions?

Arendt's approach to life-writing is unique in that she has written about inner lives keeping a distance from what Foucault has famously criticized as the 'sciences of man'. ${ }^{38}$ As Lillian Weissberg has noted, 'instead of a psychological analysis, [Arendt] proposes a turn outward, to the mimetic gesture [...] she addresses the notion of action and speaks of the public self in terms of performance [...] speech as action defines the public man. ${ }^{39}$ Of course the public realm is not necessarily the space of outside for Arendt; it is any space where action and speech meet together and human beings expose and reveal themselves to others: 'the political realm rises directly out of acting together, the "sharing of words and deeds" [...] action and speech create a space between the participants which can find its proper location almost any time and anywhere. ${ }^{10}$ In this light a literary salon could be a public space and it was actually the stage for the writing of the life of Rahel Varnhagen.

In writing Varnhagen's a life from the inside, Arendt did not discuss external facts, unless they were absolutely necessary, but she did not write within the biographical discourse of introspection either. She was interested in the life and actions of the mind, not of the soul or the psyche: 'It is inherent in the nature of the method I have selected that certain psychological observations which appear to thrust themselves forward are scarcely mentioned and not commented at all." Written as a biography, Varnhagen's text fleshes out a crucial concept of Arendt's philosophy: the idea of 'human life as a political action revealed in the language of narration." ${ }^{42}$

As a philosopher/biographer, Arendt was interested in the shape of a completed life and her narrative was a response to this life, not a representation of it. The connections with the biographical subject however were strong and passionate: Varnhagen would ultimately become "my closest friend, though she has been dead for some hundred years. ${ }^{43}$ Indeed, Arendt wrote Varnhagen's life, imagining herself in different times and different spaces: those of her biographical subject. How were these different times and spaces brought together? Arendt wrote Varnhagen's biography very much drawing on her correspondence, which she studied in the Staatsbibliothek in Berlin." Varnhagen's life was thus written in letters, which she had conceived as portraits of moments: 'I want a letter to be the portrait of a moment: that in which it is written' ${ }^{15}$ It is not accidental, Weissberg comments that Varnhagen's biography is comprised of a series of epistolary and journal quotations very much in Walter Benjamin's line in the Arcade Project and Arendt actually cites Benjamin as encouraging her to complete Varnhagen's manuscript. ${ }^{16}$ Weissberg therefore observes that writing a story from the inside, requires the author to retreat and allow the biographical subject to take charge of the biographical discourse. This of course does not mean that the authorial intention is completely erased; it rather unfolds in parallel with the voice of the biographical subject.

In the light of the discussion above, what I therefore suggest is that the Ordinary/Extraordinary series unfolds as an Arendtian project: a collage of mainly, letters, postcards and images to which Stevens responded with artistic sensitivity, intellectual rigour and unbounded passion. Luxemburg's theoretical writings are as much in the public realm and therefore political, as her love letters to Leo Jogiches; "equally Stevens' conversations with her mother and the few postcards and letters she had kept from her are 'mimetic gestures', 'actions of the public self. Given the centrality of the letters in the Ordinary Exraordinary series and

${ }^{37}$ Hannah Arendt, Rahel Varnhagen: The Life of a Jewess, ed. L. Weissberg (Baltimore: The Johns Hopkins University Press, 2000).

${ }^{38}$ Michel Foucault, The Order of Things (London: Routledge, 2000).

${ }^{39}$ L. Weissberg, 'Introduction' in H. Arendt Rahel Varnhagen: The Life of a Jewess, 19.

${ }^{40}$ Hannah, Arendt, The Human Condition (Chicago: University of Chicago Press, 1998), 198.

${ }^{41}$ Arendt, Rahel Varnhagen, 83.

${ }^{42}$ Kristeva, Life is a Narrative, 13.

${ }^{43}$ Arendt, cited in Weissberg, 'Introduction', 5.

44 It has to be noted here that Arendt first read Varnhagen's letters through the chopped and censored edition her husband circulated, shortly after her death in 1833 and which was then published as a three volumes memoir. See Weissberg, 'Introduction', 13.

45 cited in Weissberg, 'Introduction', 11.

${ }^{46}$ Ibid., 50.

${ }^{47}$ See, Elżbieta, Ettinger, ed., Comrade and Lover: Rosa Luxemburg's letters to Leo Jogiches, (Cambridge Massachusetts: The MIT Press, 1979). 
the rich body of feminist literature that has revolved around it ${ }^{18} \mathrm{I}$ was therefore puzzled and intrigued by the fact that the use of the epistolary medium in the artist's work has not been analysed as such.

What the letter reveals of course in the Ordinary/Extraordinary series is the false dichotomy between the private and the public. Lisa Tickner's article on the Ordinary/Extraordinary exhibition catalogue, ${ }^{19}$ juxtaposes, Stevens' blurb cited in the beginning of the paper with Virginia Woolf's famous extract from The Three Guineas: 'The public and the private worlds are inseparably connected; ... the tyrannies and servilities of the one are the tyrannies and servilities of the other ${ }^{300}$ But how can we get access to the private without psychologizing it? As already discussed, this is the crucial question that Arendt's work tackles with the method of 'writing from within'. In this context it is the idea of the letter as a portrait of a moment, highlighted in Arendt's biography of Rahel Varnhagen that I want to consider in relation to Stevens' work.

Although art critics have not analysed the use of letters in the Ordinary/Extraordinary series, in her recorded conversations with Patricia Hills, Stevens has referred extensively to how she was drawn to Rosa Luxemburg by reading her correspondence to her lover Leo Jogiches:

The letters between them are wonderful. She would say things like, 'You don't have to tell me everything that I must do, I can think for myself.' She would also say, 'If you would only hurry up and get your degree and come and join me, we could get married, we would love each other, we would do all our political work together, and we would have a little tiny baby, just a tiny baby.' She was in every sense a real human being, a woman who wanted to marry, was in love, wanted to have a child, and wanted to combine it with a very active political life. ${ }^{51}$

Luxemburg's letters have thus triggered the very ambiguity of the Ordinary/Extraordinary distinction that Stevens was playing with in the artist's book and the subsequent art series: Rosa Luxemburg and Alice Stevens as both ordinary and extraordinary women, exposing themselves through their epistolary fragments as unique and unrepeatable, but also vulnerable, relational and dependent on significant others. As Luxemburg was writing from her prison cell in Wonke, on 28 December 1916:

See to it that you remain a human being. To be human is the main thing, and that means to be strong and clear and of good cheer in spite and because of everything, for tears are the preoccupation of weakness. To be human means throwing one's life on the scales of destiny, if need be, to be joyful, for every fine day and every beautiful cloud-oh, I can't write you any recipes how to be human, I only know how to be human ... ${ }^{\text {s2 }}$

The letter above unfolds Luxemburg's thoughts on a fundamental philosophical question: how to be human. In including it in the collage of The Artist's Book, Stevens is inspired by Luxemburg's passion for life and action, which leaves its traces in the epistolary fragment, wherein the personal and the political are clearly articulated and forcefully expressed. In writing this letter, Luxemburg breaks her isolation in prison drawing on the letter's power to bridge the gap between presence and absence and open up channels of communication with her internal reader, the addressee, but also with the whole word, the incessant cycle of the external readers of her correspondence, then and now. Luxemburg's letter is an event that shatters the spatial isolation of the prison cell and forces its readers to think about the salience and power of politics and life. Although written 'to the moment', as all letters are, in crystallizing the moment and spirit of its creation, the letter intervenes in our perception of linear time and finite life and shows that the force of human life, if rendered into a story, transcends the limitations of the life-span and enters the discourse of history, which 'ultimately becomes 'the storybook of mankind with many actors and speakers and yet without any tangible author. ${ }^{53}$ Not only do individual human lives enter the discourse of history, Arendt argues, but actually their life stories are creating conditions of possibility for history itself: 'That every individual life between birth and

${ }^{48}$ For an overview of this literature and critical essays on Stevens' work, see the two exhibition catalogues: a) May Stevens, Ordinary/Extraordinary, A Summation 1977-1984 (Boston: Boston University Art Galleries, 1984) and b) Rosa, Alice: May

Stevens, Ordinary/Extraordinary, eds. M. Dabakis and J. Bell, (New York: Universe Books, 1988). See also Hills, May Stevens.

${ }^{49}$ Lisa Tickner, 'May Stevens' in Ordinary/Extraordinary, A Summation 1977-1984.

${ }^{50}$ Virginia,Woolf, Three Guineas, (London: Penguin, 1977), 162.

${ }^{51}$ Hills, May Stevens, 43.

${ }^{52}$ Rosa Luxemburg cited in May Stevens, Ordinary/Extraordinary, The Artist's Book.

${ }^{53}$ Arendt, The Human Condition, 184. 
death can eventually be told as a story with beginning and end is the prepolitical and prehistorical condition of history, the great story without beginning and end. ${ }^{54}$

Stevens was particularly preoccupied with this idea of the unfinished story, forcefully and dramatically encapsulated in the famous ending line from Luxemburg's last known piece of writing, Order Prevails in Berlin ${ }^{35}$, an editorial she wrote for the Communist paper Die Rote Fächne, five days before she was murdered:

“Order prevails in Berlin!” You foolish lackeys! Your "order” is built on sand. Tomorrow the revolution will "rise up again, clashing its weapons," and to your horror it will proclaim with trumpets blazing:

I was, I am, I shall be!

Ich war, Ich bin, Ich werde sein, has thus become for Stevens the phrase that dominates Voices-her painting of Luxemburg's funeral-thus transforming her death from an end to an event creating possibilities for new beginnings:

When I saw the Margarethe von Trotta movie, Rosa Luxemburg, in 1986, I did not like the ending, which showed Rosa's murder by the German Freikorps soldiers. Earlier, when I did my painting Voices, which is one of the paintings about the funeral of Rosa Luxemburg and Karl Liebknecht, I wanted not to contradict the tragic ending, but to bring something else into play. So I ended up adding these words of Rosa: 'Ich war, ich bin, ich werde sein,' ('I was, I am, I will be') above the coffins. If I had done just the funeral, it seems to me I would have done what von Trotta did, which was to let the story end. I didn't want it just to end. I wanted it to bounce back, to ricochet, to indicate that this is not an ending, and there's more. I mean we're looking at this movie. We're reading these books. We're talking about her life. So it hasn't ended. ${ }^{36}$

Stevens' portrayal of Luxemburg's death as an unfinished story, foregrounds three interrelated themes in her approach to life and art: the incessant cycle of life and death, the importance of history painting and the salience of new beginnings, that is also fundamental in Arendt's philosophy: 'the fact that man is capable of action means that the unexpected can be expected from him, that [he] is able to perform what is infinitely improbable.' ${ }^{57} \mathrm{~A}$ different conceptualization of time runs through these three themes highlighted above. As Stevens has noted:

One of the things that interests me a great deal is simply the idea of time-the approaches to time and the uses of time. You spoke about my showing Alice, my mother and Rosa Luxemburg at different periods in their lives, and I think one of the most interesting things that I've tried to work with is crossing time-by using women of different times and showing their commonalities. ${ }^{58}$

In the project of presenting different women of different times', it is not just events and individual lives that have entered the discourse of history that Stevens' artwork captures and recasts. Luxemburg's figure, her political writings, her well-known portraits and her eloquent letters, are repetitively connected to and juxtaposed with Alice Stevens' postcards, family photographs, reflections of her daughter and reminiscences of conversations with her, but mostly with her silences:

Sometimes she held me, rocked me. But she had no words to give. What she wanted to say became too big to be sayable. And the habit of not speaking too fixed. Or, as she said, much later: too big to put your tongue around [...] They put her away in a place for people who can't speak, or speak in tongues. After many years she stopped being angry ... She had gained the ability to speak, but lost a life to speak of ... ${ }^{59}$

\footnotetext{
${ }^{54}$ Ibid.

55 The editorial was published on January 14, 1919. For the whole editorial, see (http://www.marxists.org/archive/luxemburg/1919/01/14.htm, retrieved, 19/08/2009).

${ }^{56}$ Hills, May Stevens, 43.

${ }^{57}$ Arendt, The Human Condition, 178.

${ }^{58}$ Hills, May Stevens, 40.

${ }^{59}$ Stevens, The Artist's Book, in Witzling, 'May Stevens', 80.
} 
Stevens' narrative holds together fragments of her mother's voice, 'a tissue of narrative that was necessary because I didn't have [...] rich written material from my mother', as noted above. But Stevens' artwork makes her mother's few words reverberate and draw her out from the shadows of history:

I met a friend on the street one day in Soho, and she said, 'How's your mother?' I said, 'She died last February.' She gasped, 'Oh, gee. I'm sorry. I felt like I knew her.' And then she said, 'But everybody did.' I thought about that, you know, the way my mother had said everybody knows me. Yeah. For me I think it means that I want her to be known, even for the individual person that she is, but it also means that I want people like that not to be forgotten. For me she's not just a single person, because we all know this person. We all know her, and we may become her. She's a problem, as aging is a problem, as illness is a problem, as being a woman who does not fulfil herself is a problem. ${ }^{60}$

In this light, the Ordinary/Extraordinary series creates a very specific version of the grand genre of 'History Painting', to which of course women artists have had limited access. Tickner has suggested that 'it is possible to argue for Ordinary/Extraordinary as a kind of history painting transposed to the modern vernacular ${ }^{61}$, while Stevens has included Ordinary/Extraordinary 'in my 'history paintings' [wherein] official versions of history are deconstructed in favour of hearing silenced voices and unrecorded lives. ${ }^{162}$ Women are central in the artist's project of listening to silences and this interest is closely intertwined with her political activism in general and her feminism in particular and this is where I take up the thread of Stevens' life history again.

\section{Feminist Lines of Flight}

In Ordinary/Extraordinary it isn't just clash of cultures that I'm dealing with. I'm dealing with the lives of Rosa Luxemburg and Alice Stevens. Alice Stevens was born in Canada in 1895. Rosa Luxemburg was born in Poland in 1871. These two women who are important to me were juxtaposed by me because of the differences in their lives and because as a part of the women's movement I was very interested in the range, the span, the diversity, the problems, and the possibilities of women's lives. ${ }^{63}$

What Stevens articulates so nicely in talking about the Ordinary/Extraordinary series above is the close way her feminism and her artwork are intertwined. Stevens' involvement in the women's movement in the 60s emerged through her own lived experiences of trying to make her way in the world of art. Clearly, her years as an art student at MassArt had given her a strong foundation but she had to fight hard to overcome the hurdles that were inherent in her disadvantaged position in terms of social class and gender.

After her graduation Stevens lived in Boston for more than a year, working in unfulfilling jobs, caring for her mother and doing nothing about her art, but in 1984 she escaped to New York: 'When I left Quincy, I knew that my mother had nobody. My father couldn't deal with her. My brother was dead, and she had no friends. She had some relatives but they weren't there for her. I left. I had to. I would have died if I had stayed. ${ }^{61}$ As my genealogical work has shown, getting away has been a repetitive spatial pattern of women's lives in general and women artists' in particular. ${ }^{65}$

Life was not easy in New York either, but Stevens met her future husband, Rudolf Baranik there and followed him in Paris where a scholarship gave them the opportunity to study and work as artists for three years from 1948 till 1951. It was also in Paris that their first and only son Steven was born. On returning to New York as a family, Stevens' worst fear from the years of MassArt was realized: she became an art teacher and worked in art education for many years ${ }^{66}$ : 'My first job at Long Island City High School in Astoria

\footnotetext{
${ }^{60}$ Hills, May Stevens, 45.

61 Tickner, 'May Stevens'.

${ }^{62}$ Hills, May Stevens, 38.

${ }^{63}$ Ibid., 43.

${ }^{64}$ Ibid., 18.

${ }^{65}$ See, Maria Tamboukou, 'Leaving the self, Nomadic passages in the memoir of a woman artist, Australian Feminist Studies, 24, no.61 (2009): 307-324.

66 Stevens worked as an art teacher first in High Schools, the prestigious New York High School of Music and Art amongst others till the late 1950s and then at the School of Visual Arts from 1961 to 1996, mainly on part-time
} 
Queens, was very stressful for me. It was hard, partly because if you want to be a good teacher, you cannot do it halfway. You throw yourself into it. ${ }^{67}$ Although 'throwing herself in education, Stevens did not abandon her promise not to stop painting. As a matter of fact she drew on the strength of doing art to navigate the rough waters of the high school:

Long Island City High was supposed to be a very tough school [...] I chose three or four women teachers, who were really good and successful, to go to for help [...] The best person that I talked wit was Lucille, who was a black woman who taught science [...] I told her 'I am scared of the kids, I don't know what to do. I don't feel I have control.' Then I told her about my life, how I'd come back from Paris, where I had been for three years. How I had a child born in France and had exhibitions at the Salon des Jeunes Peintres, the Salon d Automne and the Salon de Femmes Peintres. When I finished she said, 'You know what you have to do? Tell the students who you are'. Wasn't that brilliant? So I went into the classroom and I told them. And it made a difference. I became a real person to them rather than just an ineffectual teacher. ${ }^{68}$

Stevens's narrative about her experience in art education unfolds in an Arendtian way, revealing the force of the who in exposing the vulnerability of human existence and in making connections with others. In talking with other women teachers and in telling her story to her students, Stevens found a way to survive in a harsh inner city school and although she moved on to further and higher education later on in her career, teaching supported and sustained her throughout her working life, creating the material conditions that would allow her to keep painting. As I have written elsewhere, ${ }^{69}$ rather than being perceived as separate and antagonistic fields, education and art should be analysed as an assemblage of personal stories, institutional arrangements, specific discourses and histories and complex social and cultural networks. As a DeleuzoGuattarian concept reconfigured by Manuel de Landa, the assemblage enables a new philosophical understanding of social entities that 'should account for the synthesis of the properties of a whole not reducible to its parts. ${ }^{170}$ Conceived as a theory of 'wholes whose properties emerge from the interactions between parts' ${ }^{\prime \prime}$ the assemblage throws new light onto the historically difficult problem of the micro-macro relations and can therefore give 'a sense of the irreducible social complexity characterizing the contemporary world. ${ }^{72}$ In this context and considering the art/education assemblage, power relations and forces of desire are constantly at play in creating conditions of possibility for women to resist, imagine themselves becoming other and for new possibilities in their lives to be actualized.

But it was not only education that sustained and supported Stevens' journey in becoming an artist. It is not surprising that in confronting the harsh conditions of schooling, Stevens turned to other women teachers for support and advice. Women's networks and the emerging women's movement would indeed become crucial in her life and art. "When we returned from Paris, I read Simone de Beauvoir's La Vieillesse [...] I also read The Second Sex [...] I was always a feminist in some sense [...] There were many meetings in New York in which we discussed feminist issues. ${ }^{73}$ Being politically active in the civil rights movement and the peace movement and protests in the 1960s and 70s, Stevens also became actively involved in several women's groups and these activities ended up in two important interventions: the establishment of an art school, The Feminist Art Institute, and the publication of the feminist journal Heresies. "We wanted something that would last. There were many suggestions. Miriam [Shapiro] very much wanted a school, because she wanted to do what she had done in California. Lucy [Lippard] wanted a magazine. Both happened. ${ }^{14}$

Schapiro's idea of The Feminist Art Institute sprang indeed from her previous experience with Judy Chicago in California, an event that has influentially shaped ideas and perceptions around a feminist

contracts.

${ }^{67}$ Hills, May Stevens, 27.

68 Ibid.

${ }^{69}$ See, Maria Tamboukou, 'Charting Cartographies of Resistance: Lines of Flight in Women Artists' Narratives, Gender and Education, forthcoming.

${ }_{70}^{70}$ Manuel de Landa, A New Philosophy of Society: Assemblage Theory and Social Complexity. (London: Continuum, 2006), 4.

${ }^{71}$ Ibid., 5 .

${ }^{72}$ Ibid.

${ }^{73}$ Hills, May Stevens, 35.

${ }^{74}$ Ibid., 36. 
inspired art education: Judy Chicago's narrative from her celebrated autobiography Through the flower beautifully illustrates what I have identified above as the art/education assemblage:

I decided to go away from the city for a year, to look for a job at a college, something that I had never done before, having supported myself by teaching occasional extension classes. When I graduated from college I had vowed not to become involved with day school teaching, as I didn't want to be like my teachers who had become more invested with their teaching than their art-making. Now I wanted to teach-but I wanted to teach women. I wanted to try to communicate to female students, to tell them what I had gone through in making myself into an artist. I felt that by externalizing the process I had gone through, I could examine it, which would be the first step in turning it around, and the women's class might also be the first step in making an alternative female art community. ${ }^{75}$

What Chicago portrays as a dream in her autobiographical narrative, is an alternative female art community emerging from the previously dreaded women's art class. We know from Chicago's own experiment for a feminist art education, that this dream was actually realized, creating unforeseen results not only for the students but also for herself and for education in general:

The class was as good for me as it was for the students. It was a wonderful experience to be able to share the struggles I had had and find that they were not only interesting and meaningful to the women, but provided them with information about how to help themselves. The one thing that I didn't understand at the time was that I had begun a process that was natural and organic. Once I had organized the class, taken it away from the school, given myself and the students a space of our own and a support group, provided them with a positive role model and an environment in which we could be ourselves, growth for all of us was inevitable. It almost didn't matter what we did as long as we were working at something productive. This suggests that what I stumbled on in Fresno has implications for all areas of female education. ${ }^{76}$

Chicago's feminist art education experiment deterritorialized art education from its historically imposed class and gender constraints. Spatial and institutional boundaries were transgressed and the art class was reterritorialized in a safe space, one that could support and sustain women's creativity as an open process: 'it didn't matter what we did as long as we were working at something productive'. ${ }^{n}$

One should not become over celebratory here of course. Processes of reterritorialization always carry the risks of creating new segmentarities and new constraints. Women's inclusion in Art Education and Art Institutions has created its own hierarchies and has generated new types of disciplinary techniques and exclusions. As Deleuze and Guattari have long warned us: 'You may make a rupture, draw a line of flight, yet there is still a danger that you will reencounter organizations that restratify everything, formations that restore power to a signifier, attributions that reconstitute a subject. ${ }^{78}$

Notwithstanding her active involvement in the women's movement, Stevens was from the beginning sceptical of its essentialist trends:

Schapiro had been out in California working with Judy Chicago, and the two of them were developing a theory that women's work, if it's truly women's work has round or oval forms in it, which had been suppressed in the male art world. But I'm thinking I don't like round forms necessarily [...] I was furious and I thought, I don't want these women putting me in a bind, telling me what to do. Men were telling us what to do. Are women also going to tell us what to do? ${ }^{79}$

Given her political activism in the 1950s and 60s, Stevens was adopting an intersectional approach, highlighting even from those early days that social class and race were part and parcel of women's oppression in ways that are often subtle and indiscernible. She invited the black artist Vivian Browne to join Heresies and

\footnotetext{
${ }^{75}$ Judith, Chicago, Through the Flower (London: The Women's Press, 1982), 67. My emphasis.

${ }^{76}$ Ibid., 78.

${ }^{77}$ Deterritorialization, reterritorialization, lines of flight, striated spaces and smooth spaces are central notions in Deleuze and Guattari's philosophical writings, particularly elaborated in their collective work, A Thousand Plateaus. For a

discussion of these concepts in relation to art/education, see Tamboukou, 'Machinic Assemblages'.

${ }^{78}$ Ibid., 9 .

${ }^{79}$ Hills, May Stevens, 35.
} 
together they edited a special issue on race, called Racism is the Issue. The whole Ordinary/Extraordinary series was indeed a challenge to the universality of the women's condition and a constant reminder of the many differences amongst women.

However in the context of Deleuze and Guattari's geophilosophy, where we start from or where we end upbeginnings and endings-are not so important. In their writings, they have actually put forward nomadic modes of existence: 'other ways of moving and traveling: proceeding from the middle, through the middle, coming and going, rather than starting and finishing. ${ }^{80}$ What is critical in the experience of freedom is our movement in between, when we follow lines of flight or escape, the intermezzo, the process of becoming other. Stevens' lines of flight have left their traces in the visual and textual narratives revolving around her life and emerging from her artwork and writings: in tracing these lines I have been particularly drawn by her project of re-imagining women as historical subjects, to which I now return by way of concluding this paper.

\section{Re-imagining women as historical subjects}

In writing this paper as a reflection on the effects of Joan Scott's 1985 influential essay on gender and history, Stevens' Ordinary/Extraordinary series has become an exemplar, fleshing out a crucial Arendtian concept: the force of life narratives in revealing the who, the unrepeatable uniqueness of human existence, which should stand against the detrimental effects that totalitarian classifications have brought about in the course of human history. Two women brought together in Stevens' art as unique existents, both ordinary and extraordinary in defiance of ethnic, religious, social and cultural classifications: Polish/Canadian, Jewish/Christian, middle-class/ working-class, political theorist/housewife, revolutionary/silenced-and the binarisms of what they were could go on ad infinitum.

Yet, Stevens' artwork has forced us to see that these identity positions can reveal nothing about who these women were and even less about their possibilities of becoming other. Flagging up the salience of gender as an analytical category, Scott had argued that we could rewrite history "only if we recognize that "man" and "woman" are at once empty and overflowing categories. Empty because they have no ultimate, transcendent meaning. Overflowing because even when they appear to be fixed, they still contain within them alternative, denied or suppressed definitions." ${ }^{81}$ Stevens' artwork has shown that 'man' and 'woman' are not the only 'empty' and 'overflowing' classificatory categories; in this sense it has brought together Arendt's philosophical approach to life narratives and the question of human condition with Scott's challenging proposition to deconstruct and historicize notions and categories that have been naturalized and erroneously used as explanatory tools- gendered identity and experience being two such concepts that have troubled the waters of feminist theory and praxis.

Scott's political level of analysis has maintained that 'significations of gender and power construct one another ${ }^{82}$ and in a Foucauldian vein they circulate in a cluster of power/knowledge relations. ${ }^{83}$ Education has historically created a stage for such antagonistic power relations at play and in this light it was influential in Stevens' life and art: it was through education that she surpassed the hurdles of her social class, becoming the first member in her family to go to college; it was against working in education that she strived to become an artist; it was education as a profession that supported her financially and allowed her to pursue her art and it was finally education that became the locale par excellence for feminist interventions. Yet, although education has been a rich field of gender studies, its close connections with art, need further research and analysis, particularly as constitutive planes of women's subjectivity.

What my work could add to the gaps that Scott's rich analysis identified twenty-five years ago and which I have been following in the project of writing feminist genealogies, is that notwithstanding the emptiness of the 'man' / 'woman' categories, there is a need to rethink the difference that the gender of the

\footnotetext{
${ }^{80}$ Deleuze and Guattari, A Thousand Plateaus, 25.

${ }^{81}$ Scott, 'Gender', 174.

82 Ibid.

${ }^{83}$ For a critical collection of essays on Foucault's theorization of power, see, Colin Gordon, ed, Power/Knowledge: Selected Interviews and other writings 1972-1977, (London: Harvester Wheatsheaf, 1980).
} 
researcher/biographer/artist has made in re-imagining women as historical subjects. ${ }^{81}$ To paraphrase and expand Irigaray's question ${ }^{85}$ that Scott herself highlighted in concluding the 1985 essay: Are the subjects of art and science gendered and what are the effects of this difference?

In bringing together the life stories of two ordinary/extraordinary women through her art, Stevens has assumed the role of the artist that Arendt's philosophy has identified as crucial in creating critical communities of remembrance: 'acting and speaking men need the help [...] of the artist, of poets and historiographers, of monument-builders or writers, because without them the only product of their activity, the story they enact and tell, would not survive at all' ${ }^{86}$ Within the discursive constraints of her own times and geographies, Arendt referred to 'acting and speaking men'. Although she has portrayed men and more specifically her own father ${ }^{87}$ in the Big Daddy series, ${ }^{88}$ which was a fierce critique of patriarchy, nationalism, imperialism and racism, Stevens' history paintings are exclusively portraying women. ${ }^{89}$ Some of these women are indeed the 'acting and speaking' Arendtian subjects, but as I have shown through the discussion of the Ordinary/Extraordinary series, silenced women have also become 'acting subjects' in Stevens' artwork; her paintings have thus opened up an on-going dialogue between her viewers, her paintings and history itself, responding to the idea of re-imagining women as historical subjects. In her 1985 essay, Scott had highlighted previous feminist scholarship that had pointed to the need of rewriting history:

[...] the writing of women into history involves redefining and enlarging traditional notions of historical significance, to encompass personal subjective experience as well as public and political activities [...] such a methodology implies not only a new history of women but also a new history. ${ }^{90}$

Scott was particularly interested in the development of 'such a methodology' and as an artist Stevens has made her own unique contribution in this process, which I suggest is still open. As our experience in the academy and the artworld has shown so far however, it falls on women as biographers, historians, theorists, artists, to take this process further: this is where the empty category of 'woman', becomes a politically situated perspective without which the Arendtian 'danger of oblivion' is imminent. Re-imagining women as historical subjects radicalizes our future and remains the feminist project par excellence.

\footnotetext{
${ }^{81}$ Gender is of course one of the multiple differences that should be considered here, alongside a multiplicity of differences apart from the well identified and researched ones of race and social class.

${ }^{85}$ Irigaray's question highlighted by Scott was the title of an article published in Cultural Critique in 1985: 'Is the Subject of Science Sexed?' (See, Scott, 'Gender', 175 and 180).

${ }^{86}$ Arendt, The Human Condition, 173.

${ }^{87}$ Stevens drew on her father's image in the Big Daddy series with which she worked for seven years, between 1967 and 1973. For further discussion of this work, see, Hills, May Stevens, 33-34.

${ }^{88}$ To get an idea of these paintings, please see http://www.jerseycitymuseum.org/vg_disp.cfm?setcnt=1\&srch_artist=\&srch_medium=\&srch_key=Stevens

${ }^{89}$ I refer here to Stevens' paintings, The Artists' Studio (After Courbet), 1974; Soho Women Artists, $1977-78$ and Mysteries and Politics, 1978, where Stevens portrayed herself and the community of women artists she was part of, in Rembrandt's way of large group portraits. For further discussion, see, Hills, May Stevens, 38-42. See the painting at: http://www.nmwa.org/collection/portfolio.asp?LinkID=719

${ }^{90}$ Ann D. Gordon, Mari Jo Buhle and Nancy Shrom Dye, 'The Problem of Women's History' in B. Carroll, ed, Liberating Women's History, cited in Scott, 'Gender', 153-4.
} 